\title{
PENERAPAN MODEL PROBLEM SOLVING LABORATORY TERHADAP PENINGKATAN PEMAHAMAN KONSEP KALOR PADA SISWA KELAS X SMA NEGERI 4 PALU
}

\author{
Nurbaya, Nurjannah dan I Komang Werdhiana \\ Nurbayaasisilyas@gmail.Com \\ Program Studi Pendidikan Fisika FKIP Universitas Tadulako \\ Jl. Soekarno Hatta Km. 9 Kampus Bumi Tadulako Tondo Palu - Sulawesi Tengah
}

\begin{abstract}
Penelitian ini bertujuan untuk mengetahui peningkatan pemahaman konsep kalor melalui penerapan model pembelajaran problem solving laboratory pada siswa kelas X SMA Negeri 4 Palu. Metode yang digunakan adalah eksperimen kuasi dengan the non-equivalent pretest-posttest design. Populasi penelitian ini adalah seluruh siswa kelas X SMA Negeri 4 Palu. Teknik pengambilan sampel adalah purposive sampling. Kelas X MIA 5 sebagai kelas eksperimen dan kelas X MIA 6 sebagai kelas kontrol. Instrumen pemahaman konsep berupa tes esai yang telah divalidasi oleh validator. Peningkatan rata-rata $\mathrm{N}$-gain yang mengikuti model pembelajaran problem solving laboratory adalah $27,17 \%$ yang berkriteria rendah dan peningkatan rata-rata yang mengikuti model konvensional menggunakan metode eksperimen dan demonstrasi adalah 4,15\%. Peningkatan pemahaman konsep kalor berdasarkan kategori kelompok kemampuan rendah, sedang dan tinggi untuk kelompok siswa yang mengikuti pembelajaran problem solving laboratory adalah 13,89 \% kategori tinggi, $31.08 \%$ kategori sedang dan $40 \%$ kategori rendah. Hasil perhitungan statistik dari pengujian hipotesis menggunakan uji-t didapatkan harga $t$ hitung sebesar 8,10 dan $t$ tabel pada taraf signifikansi $5 \%$ dan $d k=58$ adalah 1,67. Disimpulkan bahwa terdapat peningkatan pemahaman konsep kalor melalui penerapan model pembelajaran problem solving laboratory pada siswa kelas X SMA Negeri 4 Palu.
\end{abstract}

Kata Kunci: Problem Solving Laboratory, Pemahaman Konsep Kalor

\section{PENDAhUlUAN}

Pemahaman konsep fisika merupakan hal yang paling dasar dalam mempelajari fisika. Seorang siswa dituntut untuk memahami konsep atau fakta yang diketahuinya, sehingga siswa dapat mengembangkan kemampuannya dan menyelesaikan permasalahan yang ada. Sebagian besar konsep-konsep fisika merupakan konsep yang abstrak dan bahkan mereka sendiri tidak mengenali konsep-konsep kunci ataupun hubungan antara konsep yang diperlukan untuk memahami konsep tersebut, akibatnya siswa tidak dapat membangun pemahaman konsep yang fundamental pada awal mereka belajar fisika [1].

Berdasarkan hasil observasi, rendahnya pemahaman konsep fisika disebabkan adanya pemahaman siswa yang dipengaruhi oleh tafsiran siswa terhadap suatu konsep dan siswa tidak memiliki pengetahuan yang mendasar terhadap suatu konsep. Siswa datang ke kelas dengan membawa pengetahuan awal mengenai suatu konsep atau penjelasan suatu fenomena sebagaimana yang mereka lihat. Terkadang penjelasaan terhadap tafsiran tersebut tidak sesuai dengan penjelasan secara ilmiah [2]. Pengetahuan atau tafsiran konsep seperti ini sering terjadi dalam setiap konsep fisika seperti panas (kalor).

Banyak siswa mempunyai pengertian bahwa suatu benda yang bersuhu lebih tinggi selalu memiliki panas yang lebih tinggi pula. Mereka menyamakan begitu saja pengertian suhu dengan panas/kalor. Beberapa siswa juga menganggap bahwa suhu suatu benda tergantung pada besarnya benda. Bila benda itu besar, maka suhunya akan lebih tinggi, sedangkan bila benda itu kecil maka suhunya akan lebih rendah [2]. Pengetahuan atau tafsiran seperti inilah yang menyebabkan pemahaman konsep siswa semakin menurun.

Rendahnya pemahaman konsep juga diakibatkan adanya proses belajar mengajar di kelas yang cenderung bersifat analitis dengan menitikberatkan pada penurunan rumus-rumus fisika melalui analisis matematis [3]. El-Rabadi (2013) menyatakan bahwa dalam proses pembelajaran harus menggunakan eksperimen laboratorium khususnya fisika, dan jadwal mengajar harus mencakup kelas mingguan untuk melakukan percobaan di laboratorium, karena ini sangat meningkatkan prestasi belajar siswa [4].

Suparno (2013) menyatakan bahwa untuk mengajarkan materi fisika, khususnya fisika visual yang dilihat mata biasanya agak mudah 
dijelaskan kepada siswa [2]. Karena guru dapat menunjukkan kepada siswa gejala atau peristiwa yang sesungguhnya yaitu lewat pengalaman atau percobaan. Menurut Sumintono (2010) percobaan adalah kegiatan penerapan metode ilmiah siswa, yang dapat meningkatkan sikap kritis ataupun sikap ilmiah siswa serta dapat mengungkap fakta-fakta ataupun memverifikasi teori-teori sains [5].

Percobaan dan pengamatan dapat menghilangkan miskonsepsi siswa, dan menantang pemahaman awal mereka, apakah benar atau tidak. Untuk lebih menyadarkan siswa akan miskonsepsi mereka, ada baiknya eksperimen yang diambil adalah yang memberikan hasil berbeda dengan pemahaman konsep yang mereka tafsirkan. Oleh karena itu dengan mengalami dan mengamati percobaan yang hasilnya terus-menerus berbeda, siswa tertantang untuk mengubah gagasan atau konsep mereka [2]. Pembelajaran akan lebih bermakna jika siswa lebih aktif dan model pembelajaran yang diterapkan berdasarkan pada pengamatan siswa secara langsung. Putri dan Sutarno (2012) menyatakan bahwa pembelajar harus diberi pengalaman untuk dapat mengajukan dan menguji hipotesis melalui percobaan, merancang dan merakit instrumen percobaan, mengumpulkan, mengolah, dan menafsirkan data, menyusun laporan, serta mengkomunikasikan hasilnya baik secara lisan maupun tertulis [6].

Berdasarkan permasalahan di atas perlu strategi atau model pembelajaran yang dapat menghubungkan antara materi dan praktikum guna untuk meningkatkan pemahaman konsep siswa. Diketahui bahwa eksperimen yang sering dilakukan di sekolah adalah eksperimen model resep masakan, yaitu semua hal yang berkaitan dengan praktikum mulai petunjuk praktikum sampai alat telah disediakan oleh laboran. Model tersebut kurang menumbuhkan semangat untuk menggali pengetahuan siswa, karena semua peralatan dan perlengkapan yang akan digunakan dalam praktikum telah disediakan. Oleh sebab itu peneliti berinisiatif untuk mengembangkan proses berpikir kritis tersebut dengan menerapkan model Problem Solving Laboratory. Karena pada dasarnya kegiatan laboratorium merupakan bagian dari pembelajaran sains, tampaknya pemecahan masalah (problem solving) juga cocok digunakan sebagai basis dari suatu kegiatan laboratorium. Model pembelajaran Problem Solving Laboratory adalah salah satu model pembelajaran yang menitikberatkan keaktifan siswa dalam proses pembelajaran. Pembelajaran diarahkan agar siswa lebih aktif dan mampu menyelesaikan masalah secara sistematis dan logis, yaitu dengan menyajikan suatu permasalahan yang bersifat nyata dengan dunia realita siswa yang dapat dipecahkan melalui aktivitas di laboratorium [7].

Banyak penelitian yang telah dilakukan dengan menerapkan model pembelajaran Problem Solving Laboratory. Berdasarkan penelitian yang dilakukan Putri dan Sutarno (2012) menunjukkan bahwa peningkatan keterampilan proses sains mahasiswa yang mengikuti pembelajaran dengan menerapkan model kegiatan laboratorium berbasis problem solving secara signifikan lebih tinggi dibandingkan dengan mahasiswa yang mengikuti pembelajaran dengan menerapkan kegiatan praktikum verifikasi [6]. Penelitian yang dilakukan Hariani (2013) bahwa dengan pembelajaran Problem Solving Laboratory dapat meningkatkan keterampilan proses sains dan hasil belajar fisika siswa kelas XI di SMA Negeri 2 Tanggul [7]. Hal yang serupa juga diharapkan model pembelajaran Problem Solving Laboratory dapat meningkatkan pemahaman konsep kalor pada siswa kelas X SMA Negeri 4 Palu.

\section{METODE PENELITIAN}

Jenis penelitian yang digunakan adalah jenis penelitian eksperimen kuasi. Adapun populasi pada penelitian ini adalah seluruh siswa kelas $X$ Jurusan MIA (Matematika dan Ilmu Alam) SMA Negeri 4 Palu tahun ajaran 2014/2015 yang tersebar dalam 7 kelas. Kelas X MIA 5 sebagai kelas eksperimen yang siswanya mengikuti model pembelajaran problem solving laboratory dan kelas X MIA 6 sebagai kelas kontrol yang siswanya mengikuti model pembelajaran direct instruction dengan metode eksperimen dan demosntrasi.

Pengambilan sampel pada penelitian ini adalah purposive sampling, yaitu teknik penentuan sampel dengan pertimbangan tertentu dari guru mata pelajaran fisika pada kedua kelas di sekolah tersebut. Kedua kelas yang dipilih merupakan kelas yang dianggap homogen secara akademik.

Adapun desain penelitian yang digunakan adalah nonequivalent pretest-posttest group design. Desain ini digunakan untuk kelompok yang telah ada sebelumnya dan pengambilan kelompoknya dilakukan tidak secara acak (random) [8] Desain penelitian yang digunakan seperti pada Tabel 1.

Tabel 1. Nonequivalent Pretest-Posttest Group Design 


\begin{tabular}{|c|c|c|c|}
\hline Kelompok & Pretes & Perlakuan & Postes \\
\hline Eksperimen & $\mathrm{O}_{1}$ & $\mathrm{X}$ & $\mathrm{O}_{2}$ \\
\hline Kontrol & $\mathrm{O}_{1}$ & - & $\mathrm{O}_{2}$ \\
\hline
\end{tabular}

\section{HASIL DAN PEMBAHASAN}

Penelitian ini bertujuan untuk mengetahui peningkatan pemahaman konsep kalor siswa kelas X SMA Negeri 4 palu melalui penerapan model pembelajaran problem solving laboratory. Pada awal penelitian kedua kelas terlebih dahulu diberikan tes awal. Data tes awal digunakan untuk mengetahui bahwa kedua data berasal dari varians yang sama (homogen) atau memiliki kemampuan yang sama. Hasil data pengujian dilakukan menggunakan bantuan Microsoft Exel 2010. Skor pemahaman konsep siswa diperoleh dari tes awal dan tes akhir yang dilakukan pada masing-masing kelas yaitu eksperimen dan kontrol.Nilai rata-rata tes awal dan tes akhir dari kedua kelas dapat dilihat pada Gambar 1.

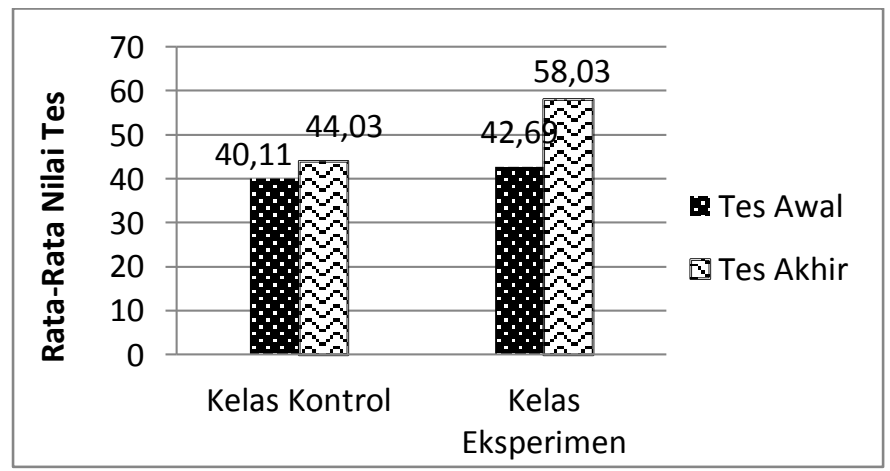

Gambar 1. Diagram Nilai Rata-rata Tes Awal dan Tes Akhir Pada Kelas Eksperimen dan Kelas Kontrol

Berdasarkan Gambar 1 dapat dilihat bahwa secara kuantitas untuk tes awal dan tes akhir terdapat perbedaan pemahaman konsep pada materi kalor antara kelas eksperimen dan kelas kontrol. Hasil pengolahan data ini selanjutnya digunakan untuk menganalisis data melalui uji normalitas, uji homogenitas dan uji hipotesis.

Berdasarkan hasil uji normalitas dengan menggunakan uji Chi kuadrat, diperoleh nilai $\chi^{2}{ }_{\text {hitung }}<\chi^{2}$ tabel baik pada tes awal, tes akhir dan rerata gain pada kelas eksperimen dan kelas kontrol. Berdasarkan kriteria pengambilan keputusan maka $\mathrm{H}_{0}$ diterima. $\mathrm{Hal}$ ini menunjukan sampel dari kelas eksperimen dan kelas kontrol berasal dari populasi yang terdistribusi normal. Uji normalitas dapat dilihat pada Tabel 2.

Tabel 2. Normalitas Distribusi Tes Awal dan Tes Akhir Pada Kelas Eksperimen dan Kelas Kontrol

Uraian Kelas Kontrol Kelas Eksperimen

\begin{tabular}{|l|c|c|c|c|c|c|}
\hline & $\begin{array}{c}\text { Tes } \\
\text { awal }\end{array}$ & $\begin{array}{c}\text { Tes } \\
\text { akhir }\end{array}$ & $\begin{array}{c}\mathrm{N}- \\
\text { Gain }\end{array}$ & $\begin{array}{c}\text { Tes } \\
\text { awal }\end{array}$ & $\begin{array}{c}\text { Tes } \\
\text { akhir }\end{array}$ & $\begin{array}{c}\mathrm{N}- \\
\text { Gain }\end{array}$ \\
\hline $\begin{array}{l}\text { Jumlah } \\
\text { Siswa }\end{array}$ & 30 & 30 & 30 & 30 & 30 & 30 \\
\hline$\chi^{2}$ hitung & 4.36 & 2.03 & 3.05 & 7.44 & 4.73 & 4.09 \\
\hline$\chi^{2}$ tabel & 7.81 & 7.81 & 7.81 & 7.81 & 7.81 & 7.81 \\
\hline
\end{tabular}

Perolehan uji homogenitas posttest kelas eksperimen dan kelas kontrol pada taraf signifikansi $\alpha=0,05$ adalah $\mathrm{F}$ hitung $=1,82$ dan $\mathrm{F}$ tabel $=1,85$. Syarat data bersifat homogen adalah $\mathrm{F}$ hitung $<\mathrm{F}$ tabel, sehingga dapat disimpulkan bahwa data kedua kelas berasal dari varians yang sama (homogen).

Pengujian hipotesis menggunakan uji-t (uji dua pihak). Kriteria penerimaan yakni $\mathrm{H}_{0}$ diterima jika $\left.\left.-\mathrm{t}_{(1-0.5} \alpha\right)<\mathrm{t}<\mathrm{t}_{(1-0.5} \alpha\right)$ pada taraf nyata $\alpha=0,05$ dan $\mathrm{dk}=\mathrm{n}_{1}+\mathrm{n}_{2}-2=30+30$ - $2=58$. Berdasarkan daftar tabel distribusi $t$ diperoleh harga $t_{\text {tabel(0,95)(58) }}=1.67$ sedangkan $t_{\text {hit }}=8,10$. Hal ini menunjukkan bahwa $t_{\text {hitung }}$ berada diluar daerah penerimaan Ho. Dengan demikian $\mathrm{H}_{1}$ diterima dan $\mathrm{H}_{0}$ ditolak. Artinya bahwa pemahaman konsep siswa yang mendapatkan pembelajaran problem solving laboratory lebih meningkat dari pemahaman konsep siswa yang mendapatkan pembelajaran konvensional.

Adapun nilai rata-rata peningkatan pemahaman konsep yang diperoleh melalui hasil analisa data menggunakan N-Gain untuk kelas eksperimen dan kontrol ditunjukan pada Tabel

\begin{tabular}{|c|c|c|c|}
\hline Uraian & Tes awal & Tes akhir & $\begin{array}{c}\text { Rerata } \\
\text { Gain }\end{array}$ \\
\hline Kelas Eksperimen & 8,43 & 11,66 & 27,17 \\
\hline Kelas Kontrol & 8,06 & 8,70 & 4,15 \\
\hline
\end{tabular}

3.

Tabel 3. Hasil Uji Peningkatan Pemahaman Konsep Pada Kelas Eksperimen dan Kelas Kontrol

Tabel 3 menunjukan bahwa rata-rata peningkatan pemahaman konsep materi kalor pada kelas eksperimen dan kelas kontrol berada pada kriteria rendah. Tetapi jika ditinjau secara kuantitatif untuk kelas eksperimen lebih unggul dari kelas kontrol, dengan nilai rata-rata N-Gain untuk kelas eksperimen sebesar $27,17 \%$ sedangkan untuk kelas kontrol $4,15 \%$. Perolehan nilai rata-rata peningkatan pemahaman konsep siswa kelompok eksperimen dan kontrol dapat dilihat pada Gambar 2. 


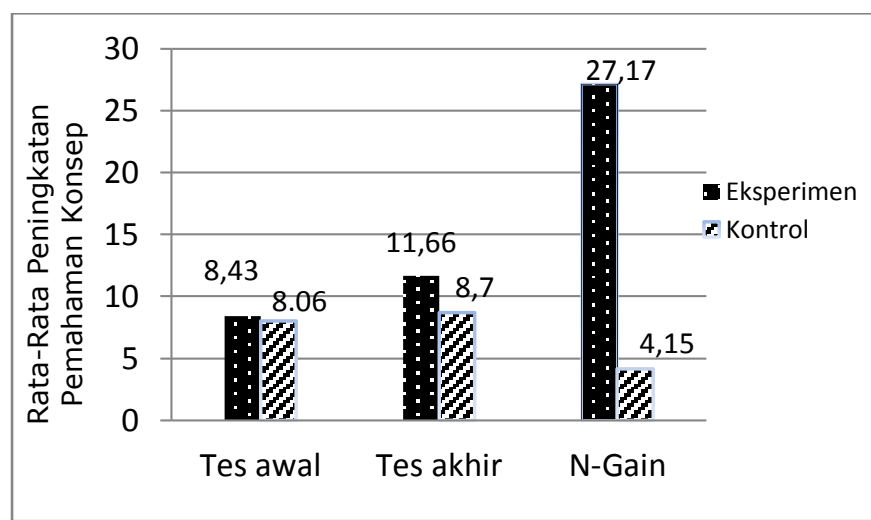

Gambar 2. Diagram Nilai Rata-rata Peningkatan Pemahaman Konsep Kelas Eksperimen dan Kelas Kontrol

Analisis hasil peningkatan pemahaman konsep siswa pada masing-masing kategori sesuai dengan kriteria kemampuan rendah, sedang dan tinggi pada kelas kontrol dan kelas

\begin{tabular}{|c|c|c|c|c|}
\hline $\begin{array}{c}\text { Kelompok } \\
\text { Kemampuan }\end{array}$ & $\begin{array}{c}\text { Rerata } \\
\text { tes } \\
\text { awal } \\
\end{array}$ & $\begin{array}{c}\text { Rerata } \\
\text { tes } \\
\text { akhir } \\
\end{array}$ & $\begin{array}{l}\text { Rerata } \\
\mathrm{N} \text {-Gain } \\
\end{array}$ & $\begin{array}{c}\text { Kategori } \\
\mathrm{N} \text {-Gain }\end{array}$ \\
\hline Kélonggiok & Rerata & Reratates & 13 Réata & Rekatabori \\
\hline Kespadlahyan & 382.33 & $59 \mathrm{kgio}$ & 31.08ain & Sedrafiajin \\
\hline Rënglgih & 25250 & 545000 & 40.10000 & Serteantgh \\
\hline Sedang & 38.82 & 42.35 & 6.00 & Rendah \\
\hline Rendah & 28.00 & $35.00 \mathrm{~s}$ & 9.70 & Rendah \\
\hline
\end{tabular}

eksperimen dapat dilihat pada Tabel 4 dan 5.

Tabel 4. Peningkatan Pemahaman Konsep Siswa Kelompok Sedang, Rendah dan Tinggi Pada Kelas kontrol

Tabel 4 menunjukkan bahwa tidak terjadi peningkatan pemahaman konsep yang signifikan untuk kelompok kemampuan rendah, sedang dan tinggi. Rerata tes awal dan tes akhir menunjukkan kemampuan pemahaman konsep siswa berada pada kriteria rendah.

Tabel 5.Peningkatan Pemahaman Konsep Siswa Kelompok Sedang, Rendah dan Tinggi Pada Kelas Eksperimen

Berdasarkan Tabel 5 terlihat bahwa secara kuantitatif kelompok kemampuan pemahaman konsep pada kelas eksperimen terjadi peningkatan dari rerata tes awal berkategori rendah sebesar 25, kategori sedang 38,33 dan kategori tinggi 55 menjadi rerata tes akhir kelompok berkemampuan rendah, sedang dan tinggi sebesar 55, 57,50 dan 61,25.

Hasil analisa data Gain menunjukan bahwa pemahaman konsep kalor siswa SMA Negeri 4 Palu yang mendapatkan pembelajaran Problem Solving Laboratory lebih meningkat dari kelompok siswa yang mendapatkan pembelajaran konvensional. Baik secara kelompok kelas maupun kelompok kemampuan pemahaman konsep berdasarkan tingkat kategori rendah, sedang dan tinggi.
Keunggulan model pembelajaran problem solving laboratory yang dirasakan peneliti saat melakukan penelitian. Diantaranya hampir seluruh siswa aktif dalam proses pembelajaran sehingga guru hanya berperan sebagai fasilitator. Para siswa juga dapat menguasai materi yang diajarkan dengan pemahaman konsep yang lebih kuat dibandingkan dengan pembelajaran konvensional. Hal ini karena dua hari menjelang pembelajaran dilakukan, kelompok siswa diberi LKS pre eksperimen (diskusi) yang berisi: penyajian masalah, pengenalan alat-alat eksperimen dan prediksi yang harus dilakukan siswa. LKS pre eksperimen ini dikerjakan secara berkelompok di rumah siswa. Kemudian pada saat pembelajaran berlangsung hasil rumusan masalah, pemilihan alat eksperimen, hasil prediksi siswa dan langkah-langkah eksperimen didiskusikan sebelum melakukan eksplorasi. Sehingga siswa telah memiliki pengetahuan awal tentang materi yang akan diajarkan dan dapat memudahkan siswa dalam menentukan konsep fisika yang terjadi pada saat melakukan percobaan.

Pernyataan tersebut juga didukung oleh penelitian-penelitian sebelumnya yaitu Hariani (2013) menunjukan bahwa hasil belajar dan keterampilan proses sains yang didapat siswa melalui model pembelajaran tersebut lebih tinggi dibanding dengan siswa yang mendapat pembelajaran konvensional [7]. Subali (2010) yang menilai kualitas pelaksanaan praktikum fisika dasar dari hasil penelitiannya menunjukkan bahwa melalui penerapan model praktikum problem solving laboratory telah berhasil meningkatkan kualitas pelaksanaan praktikum Fisika Dasar 1 [9]. Indikator dari meningkatnya kualitas praktikum tercermin dari peningkatan hasil belajar mahasiswa dan aktivitas belajarnya. Berdasarkan hasil pengamatan pelaksanaan praktikum fisika dasar terlihat pada saat kegiatan praktikum pada setiap siklusnya terjadi peningkatan aktivitasnya, baik untuk kegiatan pra praktikum, pada saat praktikum dan presentasi hasilnya. Selanjutnya Sutarno (2013) dalam penelitiannya yaitu pengaruh penerapan praktikum virtual berbasis problem solving juga berhasil meningkatkan kemampuan berpikir kritis mahasiswa [10].

Kelebihan dari model pembelajaran ini dibandingkan dengan pembelajaran langsung adalah keaktifan siswa. Melalui model pembelajaran ini siswa dilibatkan untuk aktif berfikir dan menemukan secara langsung pengertian atau konsep yang ingin diketahuinya. Selain dari kelebihan tersebut, adapula 
kekurangan dari model ini yaitu membutuhkan waktu yang cukup lama dalam bereksperimen untuk memperoleh kesimpulan atau suatu konsep yang utuh. Sehingga, dari hasil analisis skor rata-rata yang diperoleh masih dalam kriteria rendah, karena masih terdapat beberapa siswa yang melakukan aktivitas lain pada saat bereksperimen. Guru (fasilitator) juga butuh kesabaran yang lebih dalam membimbing siswa agar dapat fokus dalam melakukan kegiatan pembelajaran.

\section{KESIMPULAN DAN SARAN}

Berdasarkan hasil penelitian dan analisa data hasil penelitian, maka dapat disimpulkan bahwa rata-rata pemahaman konsep kalor siswa pada tes awal untuk kelas eksperimen dan kelas kontrol adalah 40,11 dan 42,69. Setelah diberikan perlakuan diperoleh rata-rata pemahaman konsep kalor pada tes akhir untuk kelas eksperimen 58,03 dan kelas kontrol 44,03. Signifikansi hasil uji hipotesis diperoleh bahwa harga $t_{\text {hit }}$ tidak berada dalam kriteria daerah penerimaan $\mathrm{H}_{0}$ sehingga $\mathrm{H}_{1}$ diterima pada taraf nyata $a=0,05$. Pemahaman konsep siswa yang mendapatkan pembelajaran problem solving laboratory lebih meningkat dari siswa yang mendapatkan pembelajaran konvensional pada kelas X SMA Negeri 4 Palu.

Berdasarkan kesimpulan ada beberapa saran yang dapat dikemukakan: (1) Sebelum pelaksanaan pembelajaran dengan model ini diharapkan data karakteristik siswa dan kemampuan setiap siswa agar pembagian kelompok merata dan kegiatan pembelajaran dapat terlaksana dengan baik. (2) Model pembelajaran problem solving laboratory dan model konvensional menggunakan metode eksperimen membutuhkan waktu yang cukup lama, sebaiknya guru dapat memperhitungkan waktu disetiap fase pembelajaran agar lebih efisien, karena waktu menjadi salah satu kendala dalam proses pembelajaran. (3) Untuk peneliti selanjutnya dapat menerapkan model problem solving laboratory dan membandingkan dengan model pembelajaran lainnya.

\section{DAFTAR PUSTAKA}

[1] Ihsanudin, M. (2013). Penggunaan Peta Konsep Berbantuan Multimedia Untuk Meningkatkan Pemahaman Konsep Fisika Siswa SMP. Universitas Pendidikan Indonesia.

[2] Suparno, P. (2013). Miskonsepsi dan Perubahan Konsep dalam Pendidikan Fisika. Jakarta : PT Gramedia Widiasarana Indonesia.
[3] Mariati, P.S. (2012). Pengembangan Model Pembelajaran Fisika Berbasis Problem Solving Untuk Meningkatkan Kemampuan Metakognisi Dan Pemahaman Konsep Mahasiswa. Jurnal Pendidikan Fisika Indonesia 8 (2012) 152-160. [Online]. Tersedia di http://journal.unnes.ac.id/index.php/jpfi.

[4] El-Rabadi, E.G.S. (2013). The Effect of Laboratory Experiments on the Upper Basic Stage Students Achievement in physics. Journal of Education and Practice. Vol.4, No.8, 2013. (Online). Tersedia dalam http:// www.iiste.org.

[5] Sumintono, B, dkk. (2010). Pengajaran Sains dengan Praktikum Laboratorium Perspektif dari guru-guru sains SMPN di Kota Cimahi. Jurnal Pengajaran MIPA, Volume 15 No. 2 Oktober 2010 hal.120-127.

[6] Putri, D.H dan Sutarno, M. (2012). Model Kegiatan Laboratorium Berbasis Problem Solving Pada Pembelajaran Gelombang dan Optik Untuk Meningkatkan Keterampilan Proses Sains Mahasiswa. Jurnal Exacta, Vol. X. No. 2 Desember 2012.

[7] Hariani, F. (2013). Pengaruh Model Problem Solving Laboratory terhadap Keterampilan Proses Sains dan Hasil Belajar Fisika Siswa Kelas Xi Di Sma Negeri 2 Tanggul. FKIP Universitas Jember.

[8] Sugiyono. (2013). Metode Penelitian Pendidikan Pendekatan Kuantitatif, Kualtitatif dan R\&D. Bandung: Alfabeta.

[9] Subali, E.B. (2010). Penerapan Model Praktikum Problem Solving Laboratory Sebagai Upaya Untuk Memperbaiki Kualitas Pelaksanaan Praktikum Fisika Dasar. Jurnal Pendidikan Fisika Indonesia 6 (2010) 9097.

[10] Sutarno, (2013). Pengaruh Penerapan Praktikum Virtual Berbasis Problem Solving Terhadap Kemampuan Berpikir Kritis Mahasiswa. Prosiding Semirata FMIPA Universitas Lampung. 